Jurnal Ilmu Dan Teknologi Kesehatan

Vol 6, No 2, Maret 2019

ISSN: 2338-9095 (Print)

ISSN: 2338-9109 (online)

\title{
Pemeriksaan Ultrasonografi Hepar menjadi Pemeriksaan Penunjang yang Tepat untuk Diagnosa Hepatitis
}

\author{
Dimas M Anshori, Nursama Heru, Gando Sari, Helwini Istiqomah \\ Poltekkes Kemenkes Jakarta II \\ Email:dimasanshori11@gmail.com
}

\author{
Artikel history \\ Dikirim, Des $29^{\text {th }}, 2018$ \\ Ditinjau, Jan $27^{\text {th }}, 2019$ \\ Diterima, Feb $26^{\text {th }}, 2019$
}

\section{ABSTRACT}

Hepatitis is inflammation of the liver due to viral or alcohol infection. Hepatitis can cause death and the case always increases every year both in Indonesia and the world. The aim of this study is to describe and evaluate the management of examination such as patient preparation procedure, tool preparation, patient position, transducer placement, transducer used, and ultrasound image of hepatitis. This research was conducted by qualitative descriptive method. The population is all patients who perform liver ultrasound examination at RSUD Cengkareng Jakarta. The samples used were patients who performed liver ultrasound examination with clinical hepatitis. The number of samples used is 2 patients. After being analyzed and observed, ultrasonography is an accurate and accurate examination of the hepatitis case. Additional scripting techniques are sometimes required in certain cases to make the results more optimal. Based on this research, it can be expected that ultrasound modalities can be used as an appropriate supporting tool in establishing clinical hepatitis with accurate, fast, cheap and safe results.

Keywords: Hepatitis; Hepar; Ultrasound

\begin{abstract}
ABSTRAK
Hepatitis adalah peradangan hepar karena infeksi virus atau alkohol. Hepatitis bisa saja menyebabkan kematian dan kasusnya selalu meningkat setiap tahun baik di Indonesia hingga dunia. Penelitian ini bertujuan untuk mengetahui mendeskripsikan dan mengevaluasi penatalaksanaan pemeriksaan seperti prosedur persiapan pasien, persiapan alat, posisi pasien, penempatan transduser, transduser yang digunakan, dan hasil gambaran USG hepar pada hepatitis. Penelitian ini dilakukan dengan metode kualitatif deksriptif. Populasinya yaitu semua pasien yang melakukan pemeriksaan USG hepar di RSUD Cengkareng Jakarta. Sampel yang digunakan adalah pasien yang melakukan pemeriksaan USG hepar dengan klinis hepatitis. Jumlah sampel yang digunakan adalah 2 pasien. Setelah dianalisa dan diamati, ultrasonografi merupakan pemeriksaan yang tepat dan akurat dalam menggambarkan kasus hepatitis. Teknik Skrining tambahan terkadang diperlukan pada kasus tertentu agar hasilnya lebih optimal. Berdasarkan penelitian ini, dapat diharapkan bahwa
\end{abstract}


modalitas ultrasound dapat dijadikan sebagai alat penunjang yang tepat dalam menegakkan klinis hepatitis dengan hasil yang akurat, cepat, murah dan aman.

Kata kunci: hepatitis; hepar; USG.

\section{PENDAHULUAN}

Ultrasonografi (USG) adalah suatu pemeriksaan non-invasif yang memanfaatkan gelombang suara yang disalurkan melalui alat-alat ke dalam tubuh kemudian dipantulkan dan hasilnya dapat dilihat melalui layar monitor (Baradero, Dayrit and Siswandi, 2005). Berdasarkan data WHO (World Health Organization), virus hepatitis menyerang 400 juta orang di seluruh dunia. Setiap tahunnya 6-10 juta orang akan bertambah baru terinfeksi hepatitis. 1,4 juta orang di dunia akan mati setiap tahun karena hepatitis. Hepatitis ini juga banyak menyerang masyarakat Indonesia dibuktikan dengan data dari Pusat Data dan Informasi Kementerian Kesehatan Republik Indonesia, pada tahun 2013 sekitar hampir 3 juta orang penduduk Indonesia terinfeksi hepatitis. Kondisi ini meningkat 2 kali lipat dibandingkan tahun 2007 (Didik Budijanto, 2015; WHO, 2016b, 2016a).

Hepatitis adalah istilah yang digunakan untuk menggambarkan peradangan hepar. Hal ini dapat terjadi sebagai akibat dari infeksi virus atau karena hepar terkena zat berbahaya seperti alkohol. Hepatitis juga merupakan infeksi dari hepar, yang menyebabkan sel hepar mengalami kerusakan, nekrosis dan mengalami autolisis (Williams and Willkins, 2009; Muralitharan and Ian, 2015).

Ultrasonografi merupakan teknik pencitraan diagnostik yang menggunakan gelombang suara untuk memperlihatkan organ dan jaringan dalam tubuh. Frekuensi suara yang digunakan pada ultrasonografi cukup tinggi yaitu berkisar antara 1-15 MHz (Hassani, 1976; Bushberg et al., 2012; Khan, 2014; Ugwumadu, 2014). USG dapat digunakan pada hampir semua pemeriksaan organ tubuh dengan hasil yang optimal serta banyak keunggulan yang diperoleh baik oleh pasien maupun sonografer atau radiolog. Oleh karena itu USG menjadi pilihan awal untuk mendiagnosa kelainan didalam tubuh. Keunggulan USG dibandingkan dengan modalitas pencitraan diagnostik lainnya meliputi tidak menggunakan radiasi pengion, bersifat non invasif, biayanya relatif lebih murah, mudah dan cepat. USG dapat menjadi alat yang sangat berguna untuk memeriksa hepar yang terdiagnosa hepatitis. USG merupakan alat pencitraan terbaik yang direkomendasikan untuk melihat penyumbatan bilier atau penyakit hepar lainnya pada klinis hepatitis dibandingkan dengan MRI dan CT Scan 
(Palmer, 2002; Bates, 2004; Anil T ahuja, 2007; Rumack et al., 2011).

Pada USG hepar dengan klinis hepatitis, alat yang digunakan; USG dengan transduser berfrekuensi 3-5 $\mathrm{MHz}$. Persiapan untuk pasien yaitu puasa 8 jam untuk pasien dewasa sedangkan untuk bayi 3 jam.(Breyer et al., 2002; Sidharta, 2006; Lutz and Buscarini, 2011). USG hepar dengan klinis hepatitis akan menampilkan gambaran hepar yang biasanya tampak normal, namun berguna untuk memeriksa penyakit lain yang berkaitan di baliknya. Pada tahap akut, perubahan sonografik secara khas mungkin tidak terlihat, namun hepar akan terlihat membesar dengan parenkim hipoekoik secara keseluruhan dan nyeri tekan pada pasien. Pada tahap kronis, ukuran hepar tampak mengecil, menjadi nodular dan kasar.(Breyer et al., 2002; Sidharta, 2006; Anil T ahuja, 2007; Schmidt, 2007; Bates, 2011; Carmody, Moore and Feller-Kopman, 2011)

\section{METODE}

Jenis penelitian yang digunakan pada penelitian ini yaitu dengan teknik studi kasus pemeriksaan USG hepar dengan klinis hepatitis dengan metode penulisan yang digunakan berupa kualitatif deskriptif yaitu dengan melakukan observasi serta pengamatan dilapangan kemudian penelitian ini diarahkan untuk mendeskripsikan dan mengevaluasi dengan penjelasan ilmiah. Penelitian dilakukan di RSUD Cengkareng Jakarta pada bulan Desember 2016 hingga Juni 2017.

Populasi yang digunakan adalah semua pasien yang melakukan pemeriksaan USG hepar. Sampel yang diambil berjumlah 2 orang pasien dengan menggunakan teknik pengambilan sampel purposive random sampling. Kriteria pasien yang digunakan yaitu terdiagnosa hepatitis.

Dalam penelitian ini, menggunakan instrumen penelitian antara lain pesawat USG Philips HD15 PureWave, printer merk Mitsubishi tipe B/W P95, lembar kerja, form ekspertise hasil, tissue dan jelly.

Data yang diperoleh berdasarkan klinis hepatitis dimasukkan ke dalam lembar kerja untuk dicatat dan kemudian diolah. Analisis dilakukan dengan cara mengevaluasi semua prosedur, Teknik Skrining dan hasil gambaran USG hepar klinis hepatitis yang telah dilakukan. Kemudian mendeskripsikan hasil penelitian yang telah diperoleh secara narasi dan deskriptif sehingga dapat diperoleh suatu kesimpulan.

Persiapan pasien yang dilakukan sebelum dilakukan tindakan USG hepar adalah puasa makan 4 jam sebelum pemeriksaan dan masih diperbolehkan untuk minum air 
putih. Posisi pasien pada pemeriksaan USG hepar dimulai dengan posisi pasien tidur telentang atau supine di atas meja pemeriksaan. Transduser yang digunakan bagi pasien USG hepar dengan frekuensi 3 MHz. Teknik Skrining pada pemeriksaan USG hepar mulai dengan transduser transversaldi hipokondriak kanan untuk evaluasi hepar lobus kanan dan transducer longitudinal di epigastrium atau di bawah processus xypoideus untuk evaluasi hepar lobus kiri. Skrining tambahan diperlukan sesuai dengan temuan kasus di lapangan. Apabila ditemui ada nodul, maka lakukan Skrining dengan proyeksi yang berbeda dan lokasi yang berbeda yang dalam kasus ini dilakukan Skrining pada midaxilla dengan proyeksi longitudinal dan lakukan pengukuran pada nodul tersebut. Apabila ditemui pembesaran hepar, lakukan Skrining dengan perbedaan depth agar pengukuran hepar dapat optimal. Lakukan pengukuran vena porta juga diperlukan jika diduga ada dilatasi.

\section{HASIL DAN PEMBAHASAN}

Pasien A berumur 54 tahun dari rawat inap. Pasien mengeluhkan rasa mual, sulit buang air besar, kaki membengkak, dan sakit perut kanan atas selama 1 minggu terakhir. Dari hasil laboratorium, terlihat peningkatan nilai fungsi hati. Setelah diperiksa, terlihat ekogenitas hepar yang meningkat, parenkim yang inhomogen, strukturnya kasar,adanya cairan pada kapsula hepar, ukuran hepar yang mengecil disertai adanya nodul dan ditemui juga penebalan pada dinding kantung empedu. Gambaran tambahan agar hasilnya lebih informatif diperlukan. Skrining di daerah intercostae mdiaxilla kanan pada proyeksi longitudinal dilakukan pada pasien A sehingga struktur nodular berbentuk bulat dengan ukuran $5,40 \times 5,49 \mathrm{~cm}$ dan cairan yang mengelilingi hepar terlihat dengan jelas.

Pasien B berumur 49 dari rawat jalan Pasien mengeluhkan rasa sakit pada perut bagian atas kanan disertai mual. Buang air besar sulit dan tubuh serta mata menguning. Pemeriksaan dilakukan pukul 09:06 WIB. Dari hasil laboratorium, terlihat peningkatan nilai fungsi hati. Setelah diperiksa, terlihat adanya pembesaran ukuran hepar, ekogenitas menurun, tepi yang masih reguler, parenkim yang homogen dan curiga dilatasi pada vena porta.Skrining tambahan diperlukan yaitu Skrining dengan depth yang berbeda yaitu $28 \mathrm{~cm}$ dan pengukuran vena porta. Hal ini dilakukan agar pengukuran lobus hepar dapat optimal. Efek Doppler dan pengukuran vena porta juga diaktifkan untuk melihat aliran darah serta ukuran vena porta normal atau tidak, yang setelah diukur yaitu 1,14 dan masih dalam batas normal. 


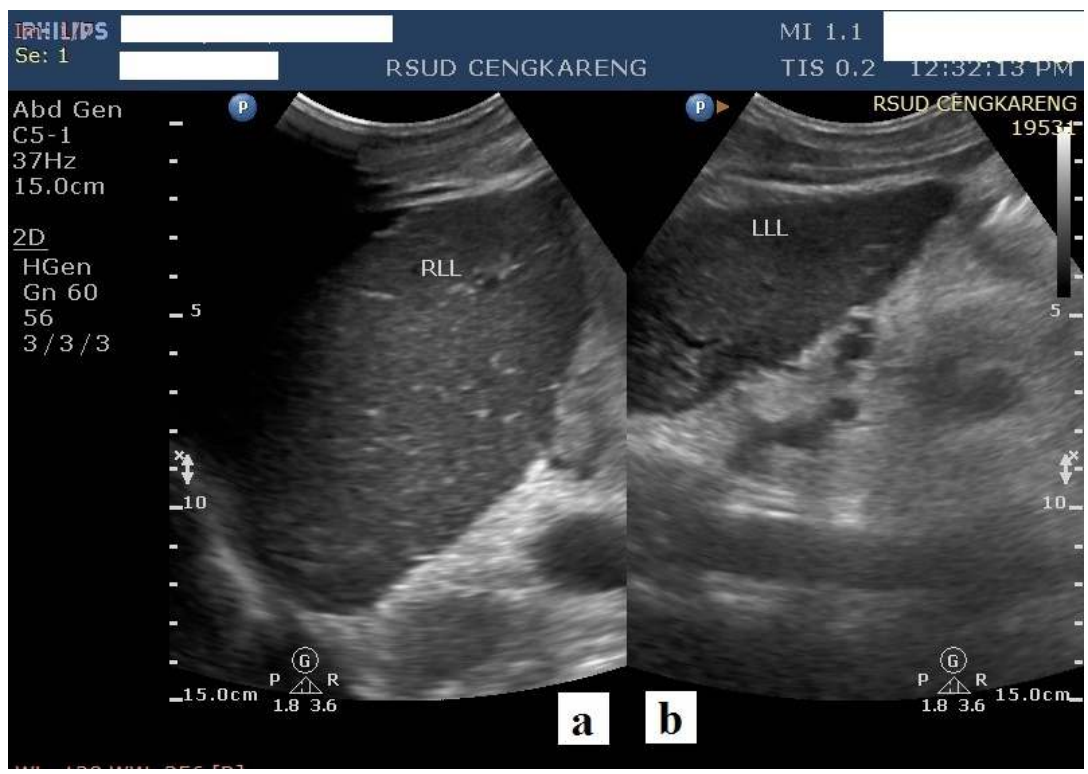

Gambar 1.Hasil gambaran USG hepar pasien A dengan tanda-tanda hepatitis kronis.

Pada gambar (1a) Lobus kanan daerah hipokondriak kanan. Pada gambar (1b) Lobus kiri daerah epigastrium. Terlihat ekogenitas yang meningkat dari normal, struktur parenkim in-homogen dan tepi irreguler serta adanya cairan disekeliling dalam kapsula hepar.

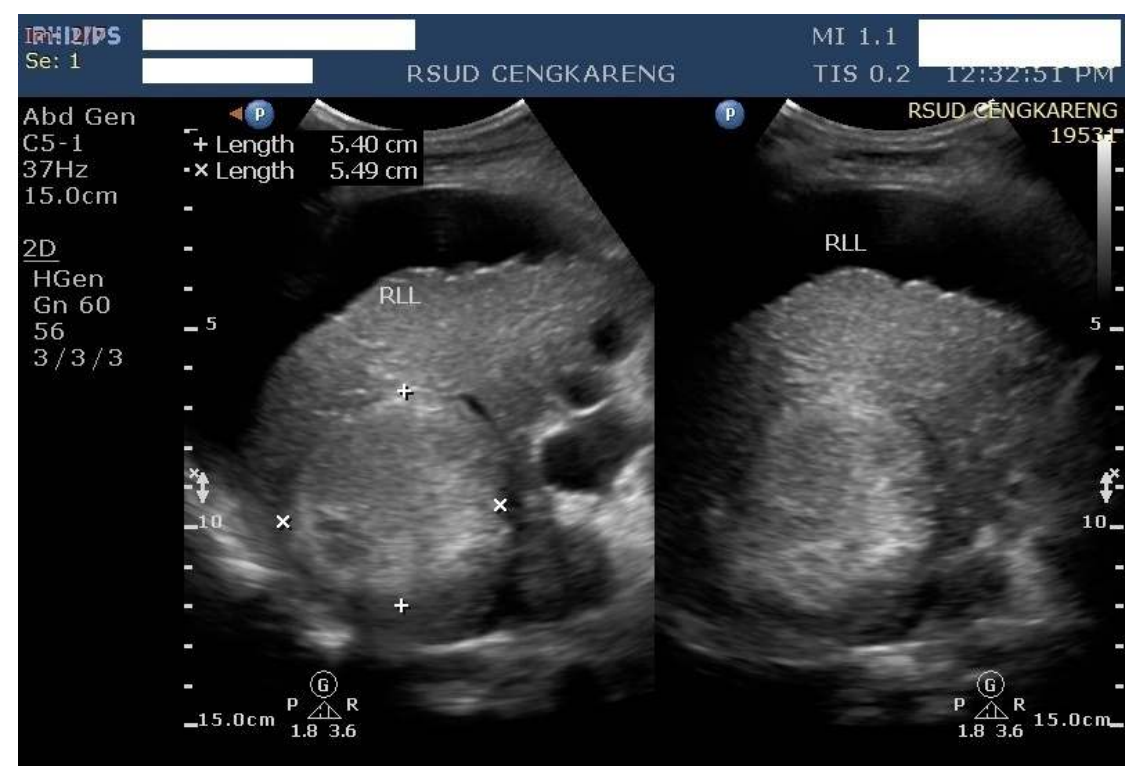

Gambar 2. Hasil gambaran USG hepar pasien A disertai dengan nodul 
Pada gambar (2) Lobus kanan dengan Skrining proyeksi longitudinal pada daerah midaxilla kanan. Terdapat gambaran anekoik yang mengelilingi hepar yang sudah mengecil dan juga ditemui gambaran struktur heterogen dengan ukuran $5,40 \times 5,49 \mathrm{~cm}$.

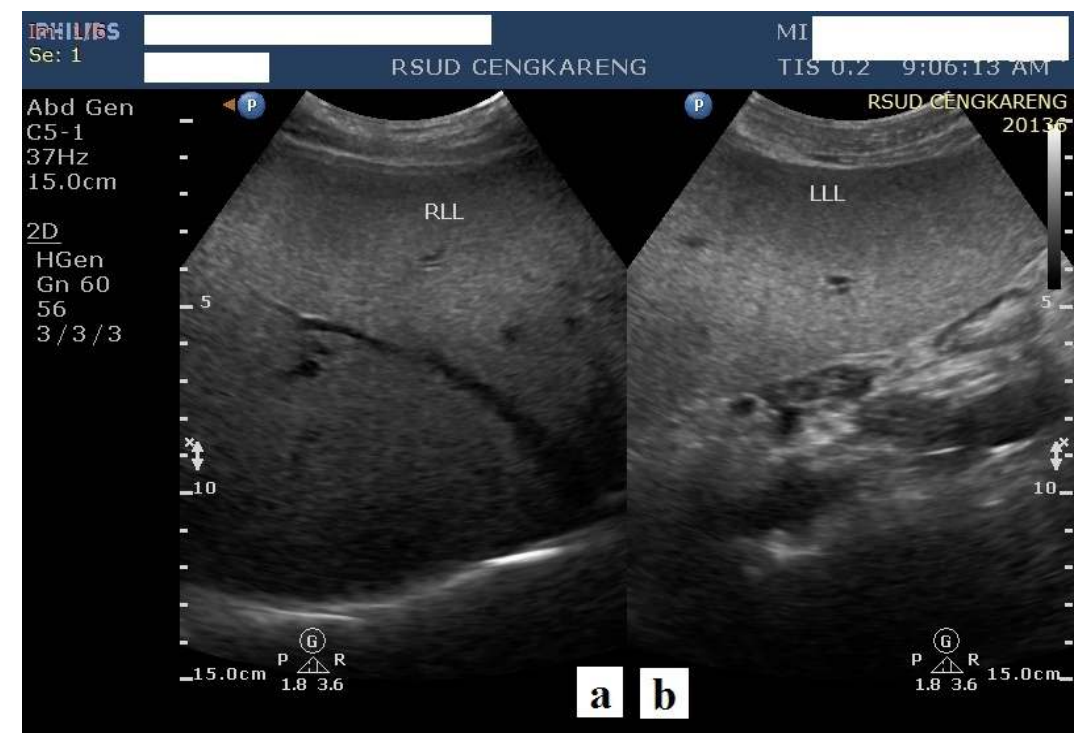

Gambar 3. Hasil gambaran USG hepar pasien B dengan tanda-tanda hepatitis akut

Pada Gambar (3) hasil dari Skrining proyeksi longitudinal pada daerah proyeksi transversal pada daerah epigastrium tampak gambaran hipokondriak kanan tampak gambaran ekogenitasnya lebih rendah dari biasanya hepar lebih hipoehoik dari biasanya dengan struktur parenkim yang kasar dan dengan struktur parenkim yang agak kasar ukuran yang membesar. dan bentuk yang membesar serta tepi yang regular. Gambar (3b) hasil dari Skrining 


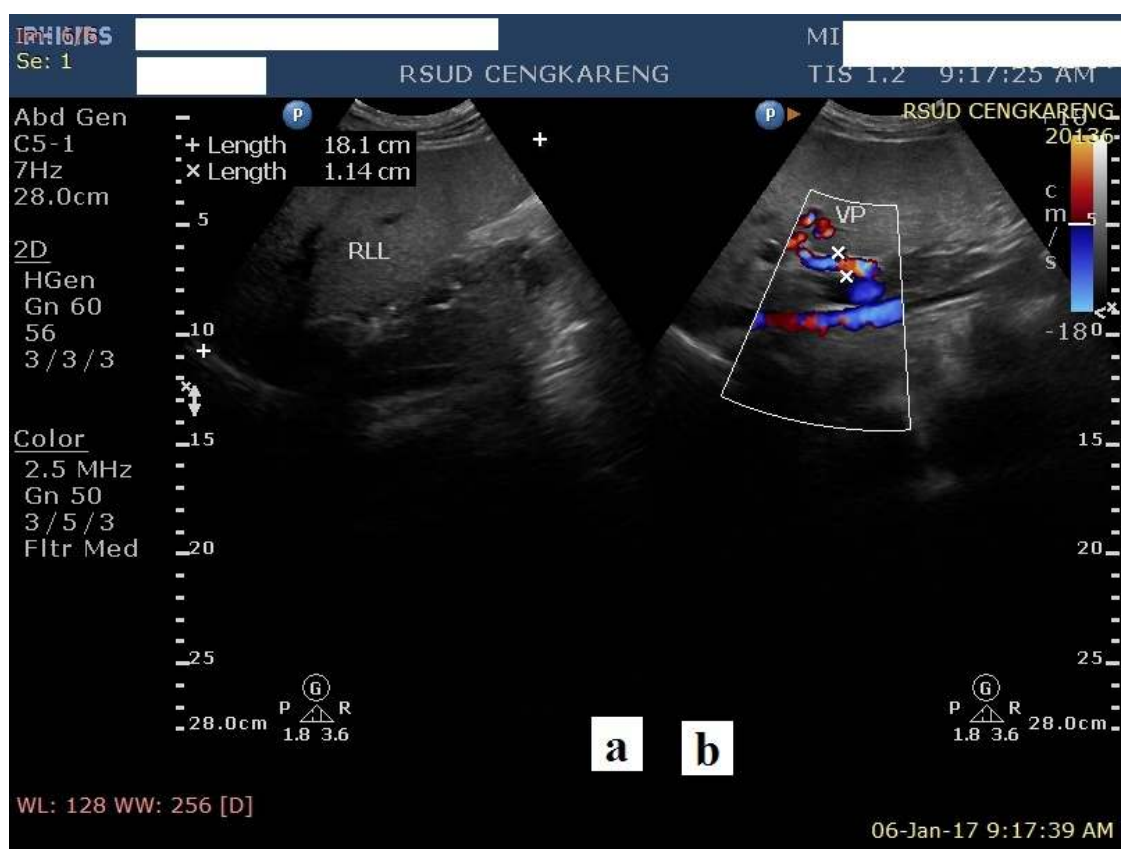

Gambar 4. Hasil gambaran USG hepar pasien B dengan depth berbeda

Pada gambar (4a) hasil dari Skrining hepar lobus kanan proyeksi transversal dengan pengukuran lobus kanan; yaitu 18 cm. Pada gambar (4b) Efek Doppler dan pengukuran vena porta pada daerah midaxilla kanan memperlihatkan ukuran vena porta dan vena hepatik yang tidak melebar serta aliran darah yang masuk masih normal ketika diperiksa menggunakan Doppler. Vena porta berukuran 1,14 $\mathrm{cm}$ yang masih dikatakan normal, dari nilai normal vena porta dibawah $1,3 \mathrm{~cm}$.

\section{SIMPULAN}

Teknik skrining yang digunakan sama dengan USG hepar pada umumnyayaitu pada hepar lobus kanan di area hipokondriak kanan, sedangkan pada hepar lobus kiri di area bawah epigastrium, pengukuran dan pengecekkan aliran darah menggunakan Doppler terkadang diperlukan. Skrining tambahan terkadang diperlukan, tergantung temuan di lapangan, seperti jika ditemukan nodul, lakukan Skrining kembali pada bagian mid axillla subcostae atau intercostae kanan proyeksi longitudinal agar lebih jelas. Jika ditemukan ukuran hepar membesar, lakukan Skrining tambahan dengan depth yang lebih dalam agar dapat dilakukan pengukuran secara lebih akurat.

Dari semua pasien yang diteliti menunjukkan bahwa pemeriksaan USG hepar di RSUD Cengkareng Jakarta cukup mumpuni sebagai alat penunjang pada kasus hepatitis. Hasil gambaran pada 
hepatitis sudah sesuai dengan literatur, walaupun puasanya lebih singkat 4 jam, tetapi sudah dapat menampilkan gambaran yang diinginkan. Hasil gambaran dibagi menjadi hepatitis kronis dan akut. Pada hepatitis kronis, ekogenitas hepar meningkat, ukuran hepar mengecil, struktur parenkim kasar dengan tepi yang irregular dan disertai dengan adanya nodul. Hasil gambaran pada hepatitis akut, ukuran hepar lobus kanan dan kiri membesar, terukur ukuran lobus kanan yaitu $18,1 \mathrm{~cm}$ dengan tepi yang regular, sedangkan Skrining pembuluh darah dengan ukuran dan aktivitas yang masih normal. Modalitas ultrasound terbukti memiliki kemampuan untuk mendeteksi hepatitis dengan cepat, murah, akurat dan aman.

\section{DAFTAR RUJUKAN}

Anil T ahuja, et al. 2007. Diagnostic Imaging Ultrasound. Salt Lake: Amirsys.

Baradero, M., Dayrit, M. W. and Siswandi, Y. 2005. Klien Gangguan Hati: Seri Asuhan Keperawatan. jakarta: EGC.

Bates, J. 2004. Abdominal Ultrasound How, Why and When. Second. New York: Churchill Livingstone.

Bates, J. 2011. Abdominal Ultrasound: How, Why and When. 3rd edn. New York : Churchill Livingstone: Elsevier.

Breyer, B. et al. 2002. Manual of Diagnostic Ultrasound. Edited by P. E.
. Palmer. Geneva: WHO.

Bushberg, J. T. et al. 2012. The Essential Physics of Medical Imaging. 3rd edn. Philadelphia: Lipponcott William and Wilkins.

Carmody, K. A., Moore, C. L. and FellerKopman, D. 2011. Handbook of Critical Care \& Emergency Ultrasound. China: The McGraw-Hill Companies.

Didik Budijanto. 2015. Pusat Data dan Informasi - Kementerian Kesehatan Republik Indonesia, July, 28.

Hassani, N. 1976. Ultrasonography of the Abdomen. 1st edn. New York: Springer-Verlag New York Inc.

Khan, M. 2014. Pass Ultrasound Physics Exam Study Guide Notes. 2nd edn. Blue Cube Venture, LLC.

Lutz, H. and Buscarini, E. 2011. WHO Manual of Diagnostic Ultrasound. 2nd edn. Malta: Guttenberg Press.

Muralitharan, N. and Ian, P. 2015. Pathophysiology for Nurses at a Glance. UK: John Wiley and Sons Ltd.

Palmer, P. E. . 2002. 'WHO manual of diagnostic ultrasound.pdf'. California, USA: World Health Organization, pp. 93-107.

Rumack, C. M. et al. 2011. Diagnostic Ultrasound. 4th edn. USA: Mosby.

Schmidt, G. 2007. Thieme Clinial Companios Ultrasound. Stuttgart, Germany: Georg Thieme Verlag.

Sidharta, H. 2006. Atlas Ultrasonografi Abdomen dan beberapa organ penting. Jakarta: Balai Penerbit FKUI.

Ugwumadu, A. 2014. Basic Sciences for Obstetrics and Gynaecology: Core Material for MRCOG, Part 1. 1st edn. Oxford: Oxford University Press. 
139 Jurnal Ilmu Teknologi Kesehatan, Vol. 6, Nomor 2, Maret 2019, hlm:131-139

WHO. 2016a. 'Global health sector Williams, L. and Willkins, L. 2009. strategy on viral hepatitis 2016-2021', WHO. World Health Organization.

WHO. 2016b. Hepatitis B, WHO. World Pathophysiology made Incredible Easy. Ambler: Judith A. Schilling Mc Cann RN MSN.

Health Organization. 